\title{
The Problem of the Illusory Gratuity of Existence in Sartre's Philosophy
}

\section{Araujo Souza CK* \\ Centro Educacional Siqueira Campos, Brasil}

*Corresponding author: $\mathrm{M}^{\mathrm{a}}$ Carlos Kleyvon Araujo Souza, CESC, Rua Pernambuco, 1117, Aracaju, Sergipe, Brazil, Tel: +55 79 32591979; Email: 666sac@bol.com.br

\section{Conceptual Paper}

Volume 3 Issue 2

Received Date: March 23, 2020

Published Date: April 20, 2020

DOI: $10.23880 /$ phij-16000141

\section{Abstract}

Daily choices involve daily and intrinsically freedom, one of the central themes in Jean-aul Sartre's existentialist philosophy. Some scholars have this philosopher together with Karl Marx, Friedrich Nietzsche and Sigmund Freünd as the "masters of suspicion", because they revolutionized the subject's secular tradition in what corresponds to an "inner and outer self". In order to carry out this analysis, we base ourselves on the studies of Leopoldo e Silva on the illusory gratuity that the subject has when choosing a certain choice, that is, the apparent existence at no cost. In view of this, three central questions will be exposed to base the argument that Sartre defends regarding the impossibility of the intentionality of the "being ${ }^{1 \text { " choosing }}$ to $b e^{2}$ something in the same way that it can possess $^{3}$ some object. The first question concerns the meaning of existence. The second question demonstrates the importance of history for and in the individual. In the third and last one, the project is explained, the individual's intention along the way in history. It is from this intention that the freedom arises for the subject to choose something for himself or, even not to choose, as he is free even to be what he had not designed at the beginning of this journey. In view of that, Sartre tries to demonstrate that hope is, little by little, limited in the project that the subject puts on himself to be something, given its radical finitude and its exorbitant price for existence.

Keywords: Existentialism; Freedom; Philosophy; Illusion

\section{The Shock of a Heritage of Centuries}

The theme proposed in this article is about what we do with us and what we do with what they do with us, in the conception of Jean-Paul Charles Aymard Sartre (1905980). Given the theme, the hypothesis that follows is that the individual has the freedom to be what the conscience best judged for itself in the situation in which it finds itself. With this, the objective that is proposed is to demonstrate how high the price of the individual's gratuity is when he becomes aware of the responsibility for his own, and now lonely, choices and their consequences from his total indeterminacy.

This same indeterminacy is what provides, par excellence, the concept of freedom as a performance for Sartre, because it is there that contradictions, encounters and mismatches are found. This Sartrean realism - for somepeople, pessimism - is largely due to the historicalsocial context he experienced: a time of wars where naivety is lost with the historical and concrete experience of the degree of power of the cold and calculating evil in which the human being is able to submit his fellowmen.

Based on his individual experience, Sartre revolutionized the human condition together with Karl Marx, Freüd and Nietzsche by being part of what was called "masters of suspicion" by taking a critical look at tradition and undermining the foundations of a centuries-old heritage. This inheritance has always been based on the illusion of the existence of an inner and outer self. Sartre's experience determined his philosophical thinking when he perceived and questioned the unjustified and the unjustifiable in order 


\section{Philosophy International Journal}

to understand and face -Leopoldo E Silva (p. 120) an order obscurely - established.

\section{The Cost that the Gratuity of Existing Takes: The Dilution of Hope}

In the wordsof Franklin Leopoldoe Silva “(...) it's necessary to accept that the fundamental desire to be is unrealizable: our condition is radically finite and its gratuity hinders any hope $^{4 "}$-Leopoldo E Silva (p. 134), Sartre decimates with a whole legacy of centuries of history by ending the "inner and stronger self" and also with what is called the "outer, carnal self", the result of this heritage. In order to reach this conclusion, it is necessary to see three points in order to understand the fact that being is an unrealizable goal due to the impossibility of overcoming the separation of the nature of being something, for the nature of the being something. This is a significant deficiency, as it affirms that everything that is to-be is free of choice as what already is does not have free acts, not even the most expressionless act, because he did not have the right to choose, because he already.

\section{The three arguments of the impossibility of "being"}

The first point is about the meaning of existence, which for Sartre is inseparable from history based on the dialectical relationship that exists between freedom and history. This point is where, it is said, that there is no absolute freedom, there is no freedom in the void, that is, existence is a situation, the situation of the individual being constituted in history and constituting history.

The second point is that the fact that the individual occurs in history does not mean that it dissolves in it, nor that the awareness of itself should be considered a mere reflection of the conditions imposed on it. This fact must be analyzed under two importante aspects, which Sartre describes them as that of interiority and that of exteriority. Interiority assimilates the historical and concrete experience lived in a unique way by each individual, interiorizing it, that is, not being distinguished from exteriority; this is everything that has been internalized and returns to the outside world as actions of the subject, as effects of his elaborated representations. From that moment onwards, exteriorization becomes action, being the projection of the subject, of his intentions, of his desires as possibilities.

The third point concerns these intentions, this project that the individual makes of himself and that are lost in the very path of its realization due to history. In other words, these intentions are the interaction between the individual and the conditions he experiences, that is, between the subject and his action when entering into relationships with other individuals. It is seen, then, that what the subject proposals to accomplish often becomes other or even contrary to his initial intentions because of the movement of history and that is why when there is overcoming it is characteristic of the dialectical movement. At this point in his experience, man defines himself as a project, because he is all in it, even if he runs the risk of being diverted from what was initially planned. There needs to be an understanding of reality at this conjuncture when considering the final meaning from its initial conditions. The individual aware of this condition will perceive the tension and contradiction that is the totalization process, that is, of the interaction between interiority and exteriority. In this situation there is an understanding of why it is what we do with us and, at the same time, it is what we do with what they do with ourselves.

\section{The Experimentation as infinite possibilities of "being"}

As the individual is undetermined to be something or any other determined, he can find himself again throughout the planned project, without a false crystallization in terms of totalization because he has a fixed and static representation of his own being. After these demonstrations, it becomes necessary to accept that the desire to be is unfulfillable because the human condition has a radically finite existence and the gratuity of that same existence charges an exorbitant price to the human being: the inhibition of any hope.

Now, this cost is due to the fact that we are unable to transform the being into something that we can have and this effect is the fundamental desire of the being as a project. It is through this desire that the being would pass from the condition of "inconsistent", from something it lacks, to the condition of sufficient, aware of its fullness, which Sartre calls as in-itself-for-itself. This concept would be the link between consciousness and absolute consistency, exhausting any possibility of overcoming this separation as it becomes aware of not being able to achieve such an appropriation of owning in the same way that it could own an object.

\section{Conclusion}

There is room for both pleasure and frustration when researching Jean-Paul Sartre on his theme par excellence - the freedom - and it is stated by two facts: having knowledge of one's own limits and consequently of the finitude that belongs to everyone, be it a king or a monk, and the variety of sources that we cannot read all that came up when researching.

The human being's ability to always be renewing or to be renewed as he chooses is something unique among humans, which contrasts with the cost charged therefrom. The gratuitous existence that nothing seems to demand contains any spark of hope about the desire to be fully, that is, that the human being has in having himself totally as someone who has something. 
Such capacity is called radicality in the concept of Sartre, and it is due to the fact of choosing this or any other way, its origin being the total indeterminacy of the individual in being. This, brings powers to be able to project what you want for yourself.

It is not by chance that the phrase that became famous - in Jean-Paul Sartre - brought with it the exorbitant cost, which is the impediment to any possibility of hope: "man is condemned to be free"; therefore, such power comes with size and proportional cost.

\section{References}

1. Borges AT, Capelli DC, Azevedo MK, Vieira JA (2009) O conceito de liberdade no existencialismo sartreano.
Akrópolis - Revista de Ciências Humanas da UNIPAR 17(1): 13-20.

2. Cezarini da SL (2008) Um olhar sobre Hegel: Crítica da razão dialética de Jean-Paul Sartre. Intuitio 1(2): 188200.

3. Leopoldo E Silva F (2011) O Conhecimento De Si. Martins Fontes, São Paulo, Brasil, pp: 152.

4. PizzingA RD (2009) Pensamentos de Jean-Paul Sartre e... Existencialismo... de sua mulher, Simone de Beauvoir. Monografia pública. CD-ROM, pp: 28.

5. viana N (2008) Sartre e o Marxismo. Filosofia Unisinos 9(2): 146-161.

\section{NOTES}

1. Author's griffin.

2. Idem.

3. Idem.

4. “(...) é preciso aceitar que o desejo fundamental de ser é irrealizável: nossa condição é radicalmente finita e sua gratuidade tolhe qualquer esperança.” 